\title{
Life inside a gall: diversity, phenology and structure of Portuguese gall communities, their hosts, parasitoids and inquilines
}

\author{
Francisco A. López-Núñez ${ }^{1}$ (D) Sérgio Ribeiro ${ }^{1}$ Hélia Marchante ${ }^{1,2} \cdot$ Ruben H. Heleno $^{1} \cdot$ Elizabete Marchante $^{1}$
}

Received: 4 December 2017 / Accepted: 7 November 2018

(c) Springer Nature B.V. 2018

\begin{abstract}
Plant galls sustain diverse and complex communities of gallers, parasitoids and inquilines that provide exceptional systems to explore evolutionary, ecological and conservation questions. However, the structure and phenology of such communities are still largely unknown. In order to fill these gaps, we sampled plant galls along the Portuguese coast aiming to (1) characterize the diversity of gall-associated communities (plants, gallers, their parasitoids, and inquilines); (2) evaluate how richness and abundance of gallers are shaped by plant life-form; and (3) explore the phenology (i.e. emergence time) of the different guilds. For 1 year, we collected 31,737 galls from 33 plant species, revealing remarkably diverse communities centred on 49 gallers, 65 parasitoids and 88 inquiline species. The plant families with more galls were Fabaceae, Fagaceae and Cistaceae, while most gallers were Cynipidae and Cecidomyiidae. Regarding parasitoids, Torymidae and Eulophidae were the richest families, and most inquilines belonged to the families Cecidomyiidae, Thripidae, Aphidiidae and Psocoptera. Shrubs hosted a significantly greater abundance and richness of gallers. Overall community composition was highly variable in time, frequently with turnover rates greater than $50 \%$ between consecutive months. An asynchrony between life cycles of each guild could be explained by the sequential availability of resources for gallers and parasitoids and by the relaxed physiological constraints between galls and inquilines. This baseline information is vital for revealing a hidden component of biodiversity and shedding light on its community structure and resilience.
\end{abstract}

Keywords Gall-inducing insects $\cdot$ Iberia $\cdot$ Multitrophic relationships $\cdot$ Parasitoids $\cdot$ Inquilines $\cdot$ Hidden biodiversity

\section{Introduction}

Insects have been increasingly recognized as "the small things that run the world" (Wilson 1987); however, a few guilds, particularly pollinators, pests and decomposers, gathered most of the attention to date (Brian 2012; Copping 2009; Losey and Vaughan 2006). One often neglected

Handling Editor: Heikki Hokkanen.

Electronic supplementary material The online version of this article (https://doi.org/10.1007/s11829-018-9655-4) contains supplementary material, which is available to authorized users.

Francisco A. López-Núñez

lnfran85@gmail.com

1 Centre for Functional Ecology, Department of Life Sciences, University of Coimbra, Calçada Martim de Freitas, 3000-456 Coimbra, Portugal

2 Escola Superior Agrária, Instituto Politécnico de Coimbra. Bencanta, 3045-601 Coimbra, Portugal group is that of gall-inducing insects (hereafter gallers for simplicity) and their associated communities. Plant galls are formed by the growth of plant tissues as a reaction to the oviposition by a galler. During this process, the plant cells suffer an abnormal growth characterized by hypertrophy and hyperplasia, resulting from biochemical compounds secreted by galler larvae (Dorchin et al. 2009; Giron et al. 2016; Redfern and Shirley 2011). In turn, both the galler and the gall tissue can be resources for other trophic and nontrophic interactions, namely with parasitoids and inquilines, respectively, forming complex communities. These communities are exceptional systems to explore evolutionary, ecological and conservation questions (Hayward and Stone 2005). Most gallers are midges (Diptera:Cecidomyiidae) and wasps (Hymenoptera:Cynipidae), although several other insect families can induce gall formation (e.g. Coleoptera:Apionidae, Homoptera:Aphididae) as well as Acari (Eriophyidae), bacteria and fungi (Price et al. 1998; Redfern 2011). Most studies on galls have been centred on a single species, genus or family (Stone et al. 2002), 
sometimes exploring the trophic relationships with their parasitoids, as the case of Palearctic region (particularly in Iberia), where the diversity of gallers, parasitoids and inquilines is relatively well studied (Bellido and Pujade-Villar 1999; Garbin et al. 2008; László and Tóthmérész 2006; Nieves-Aldrey 2001a, b; Nieves-Aldrey and Askew 2002; Pujade-Villar and Ros-Farré 1998; Ros-Farré and PujadeVillar 1998; Skuhravá et al. 1996; Stone and Cook 1998). However, community level assessments of the interactions structuring gall communities (Kaartinen et al. 2010; Bunnefeld et al. 2018) and the importance of temporal dynamics of these communities (which influence the composition and abundance of species and consequently ecosystem functioning) have been largely ignored (but see Cuevas-Reyes et al. 2004; Hawkins and Goeden 1984; Joseph et al. 2011; Veldtman and McGeoch 2003). Although less explored, some studies highlight the impact of inquilines in the fitness of gallers and in nutrient cycles (Begon et al. 1999; Brooks and Shorthouse 1998; László and Tóthmérész 2006; Shorthouse 1998).

In Portugal, there is only a handful of studies of gall communities, including the seminal work of Joaquim Tavares in the beginning of twentieth century (Tavares 1900, 1902, 1905, 1907) and some more recent work with Quercus and Eucalyptus galls (Askew et al. 2006, 2013; Branco et al. 2006, 2009; Inácio et al. 2002).

Different gallers induce the formation of highly characteristic galls and the association between plants and gallers is highly specific, to the point that it is possible to identify the galler based on the plant species and on the morphology of the gall (Redfern 2011; Redfern and Shirley 2011; Russo 2006). Given their specificity, galls have been used as biocontrol agents of invasive plants (Impson et al. 2008; Moran and Goolsby 2009); e.g. the Australian gall-wasp Trichilogaster acaciaelongifoliae Froggatt (Hymenoptera:Pteromalidae) has been used in South Africa since the early 1980s to control Acacia longifolia (Andrews) Willd (Hoffmann et al. 2002) and was recently introduced in coastal habitats in Portugal (Marchante et al. 2017). On the other hand, some gallers have become invasive (Csóka et al. 2017), as is the case of chestnut gall wasp Dryocosmus kuriphilus Yasumatsu, 1951 (Hymenoptera:Cynipidae) in Europe (Brussino et al. 2002), including in Portugal where it has significant economic costs (EPPO Reporting Service no. 06-2014). Nevertheless, and despite their high host specificity, some gallers or galls may share parasitoids and inquilines, respectively (Aebi et al. 2007; Quacchia et al. 2013; Askew et al. 2006, 2013; Csóka et al. 2005; Holt and Lawton 1993; Ronquist and Liljeblad 2001), which is likely to be determinant for their potential impacts either as invasive species or as biocontrol agents (López-Núñez et al. 2017; Veldtman et al. 2011).
The Iberian Peninsula, and Portugal in particular, is included in one of the world's biodiversity hotspots (Hewitt 2011). Within this region, coastal habitats are particularly vulnerable to many rapidly growing threats, such as direct pressure from anthropogenic activities, urban development, coastal erosion, sea level rise and invasive species (Heslenfeld et al. 2004). However, although a network approach has been previously used to analyse network interactions of Portuguese coastal gall communities in the context of biological invasions and biological control (López-Núñez et al. 2017), no studies have explored the diversity, taxonomy and phenology of gall communities. In this context, we wanted to explore the communities of galls along the Portuguese coast in order to (1) characterize the diversity of gall-associated communities (plants, gallers, their parasitoids and inquilines); (2) evaluate how richness and abundance of gallers are shaped by plant life-form; and (3) explore the differences in annual phenology and turnover among the different guilds, namely testing if they have different emergence times. Additionally, this knowledge may change the perception about the importance of these hidden communities throughout the coastal habitats of Portugal; and at the same time can form an important baseline information for understanding future changes on native gall communities.

\section{Materials and methods}

\section{Sample sites}

Ten sites were selected along the Portuguese coast (Online Resource 1: Figure 1), including sand dunes, pine forests and oak woodlands with dominance of different species of shrubs and trees (Table 1). Sites were predominantly located up to $1 \mathrm{~km}$ from the ocean and all have mild winters and dry summers typical of Mediterranean climate. Four of the sites were visited monthly for 1 year and the other six were visited every 3 months (Table 1 and Online Resource 1: Figure 1). Sampling was uneven because the large number of galls and intensive lab work made it impossible to sample all sites monthly. The seasonal sampling of six of the sites, although less frequent, allowed a better representation of the whole diversity of the study region.

\section{Collection of galls and rearing of insects}

Sampling took place between August 2013 and July 2014, during which period a random transect of $20 \times 2 \times 2 \mathrm{~m}$ (length $\times$ width $\times$ height) was run in each visit and site. Transects were separated by at least $50 \mathrm{~m}$. In each transect, all plants were recorded and identified to the species level following Bingre et al. (2007) for trees and shrubs, and other 
sources for herbaceous plants (Franco 1971, 1984; Franco and Rocha Afonso 1994, 1998, 2003).

Galls detected in each transect were collected and individually stored in closed plastic containers at room temperature. When the abundance of similar galls on the same host plant made collection impossible, all galls were counted and a sub-sample was collected. Collected galls were monitored once a week during 15 months or until they rot or were damaged by fungi. Emerging insects were stored in Eppendorfs in $70 \%$ ethanol and identified to the lowest taxonomical level possible, usually species, by professional taxonomists.

Emerging insects were sorted into three different guilds: gallers, parasitoids or inquilines (Online Resource 2: Table 1) based on available literature (Chinery 2013; NievesAldrey 2001a; Noyes 2016; Redfern and Shirley 2002). Although many of the inquilines do not feed or develop strictly within galls, the term "inquiline emergence" was used for simplicity. For species with no available information, the guild was attributed based on information relative to the closest genus with a known feeding strategy. When there were no emergences from collected galls, the species of galler was inferred from gall morphology (shape, size, aspect, colour, etc.) and the identity of the host plant following Chinery (2013), Jürgen Buhr (2012), Nafría and Durante (2002), Nieves-Aldrey (2001a) and Redfern and Shirley (2002). Furthermore, since the formation of galls in organs is indicative of the contact with a galler insect, and because the effective fecundity of each species of gall is difficult to determine, we assumed that galls of each morphotypes produce the same number of gallers, in order to use the frequency of gall types as a proxy of galler abundance and diversity.

\section{Data analysis}

We characterized the diversity of each guild, as well as their phenology and emergence period, as follows.

\section{Diversity analysis}

We assessed the overall richness and abundance of plants, gallers, their parasitoids and inquilines. Plant species were classified according to their life-form as herbs, vines, subshrubs, shrubs or trees. Abundance and richness of galls were corrected by each plant species cover.

Using a Generalized Linear Mixed Models (GLMMs), we evaluated the relationship between plant family, life-form, and cover (as fixed factors) and the abundance and richness of gall species. In order to incorporate spatial autocorrelation in these models, we considered the sampling site as random factor. Dependent variables and plant cover were transformed as $x^{\prime}=\frac{-1}{(x+1)^{2}}$ and $\log (x)$, respectively, in order to reach normality and homoscedasticity of the model residuals. When the model detected significative differences, it was followed by a post hoc Tukey test. GLMMs and post hoc analyses were carried with the R packages lme 4 and multcomp (Hothorn et al. 2008; Bates et al. 2015).

\section{Rank-abundance curves}

Rank-Abundance curves were constructed and plotted in R (R Development Core Team 2011) using package Vegan (Oksanen et al. 2013). These curves characterize the taxocenosis diversity (richness and relative species abundances) and the slope informs about species dominance (Whittaker 1965).

\section{Species turnover rate}

We calculated the monthly turnover of each guild using the equation: $\mathrm{TR}=\frac{(G+L)}{T}$, where $G$ is the number of species gained, $L$ is the number of species lost and $T$ is the total number of species observed in both months (Collins et al. 2008). Turnover rates thus vary between 0 (no change) and 1 (all species change). Turnover rates were calculated with the codyn package (Hallett et al. 2016).

\section{Insect emergence}

In order to analyse the differences in the emergence phenology of insects of the different guilds, two measures were considered: (1) insect emergence distribution throughout the year, and (2) the number of days between gall collection and the emergence of insects. For this, medians and their 95\% confidence interval of the median bootstrap were calculated based on the four sites with monthly samplings. Differences were analysed with non-parametric Kruskal-Wallis tests, followed by a Dunn's multiple comparisons test with a Bonferroni correction. Post hoc analyses were carried using the FSA package (Ogle 2016).

\section{Results}

\section{Diversity analysis}

A total of 203 plant species, distributed through 54 families, were recorded (Online Resource 2: Table 1). Galls were observed in 33 of these plant species from 13 families (Fig. 1a). Among these, Fabaceae, Fagaceae and Cistaceae the most common, encompass $33 \%, 15 \%$ and $12 \%$ of the plant host species, respectively. Although galls were observed in all sampled species of Fagaceae, Salicaceae, Anacardiaceae, Lauraceae and Rhamnaceae, these families were represented by only a few plant species. On the other 
(a)

Plant Families

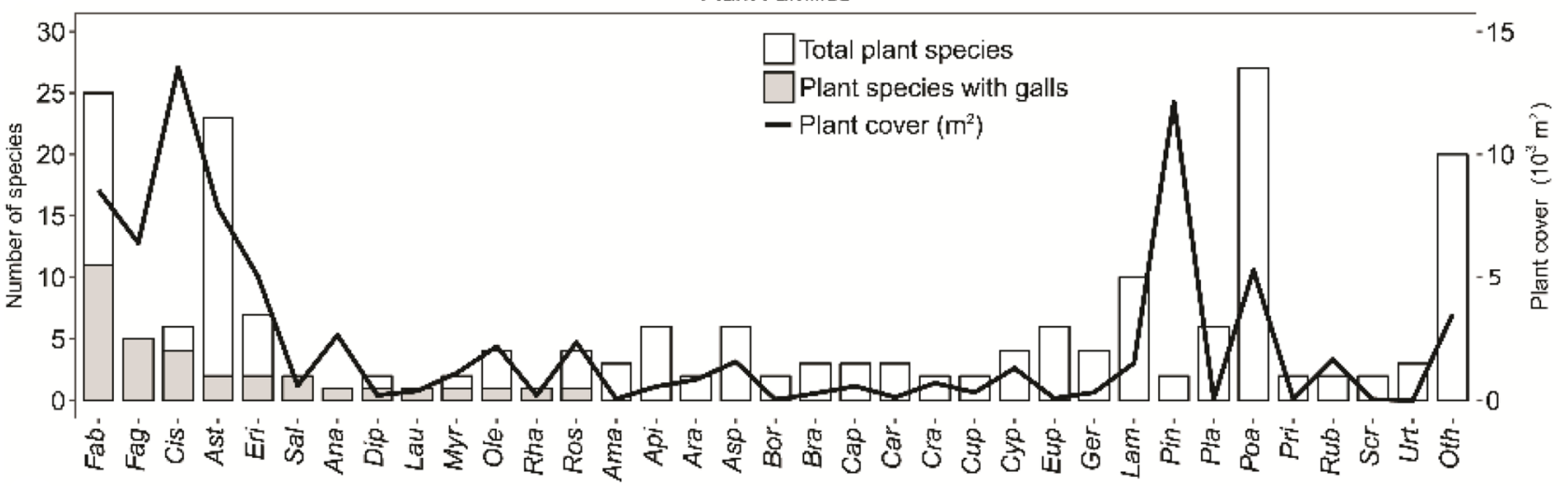

(b)

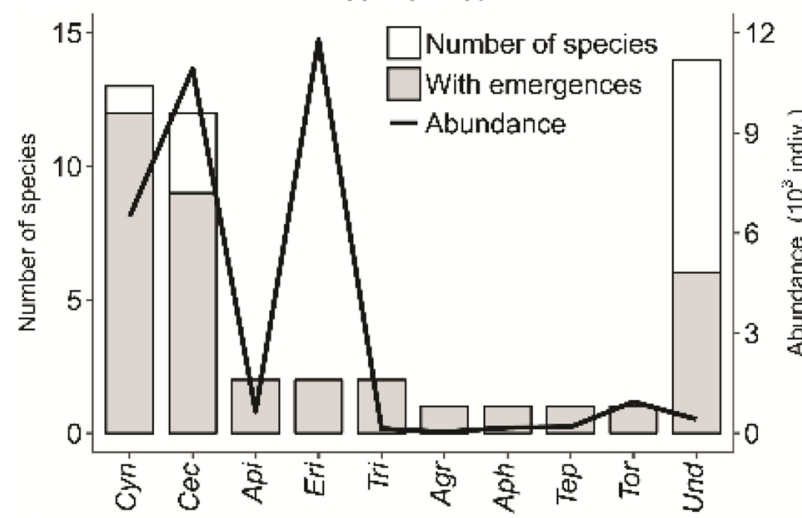

(c) Parasitoid Families (d)

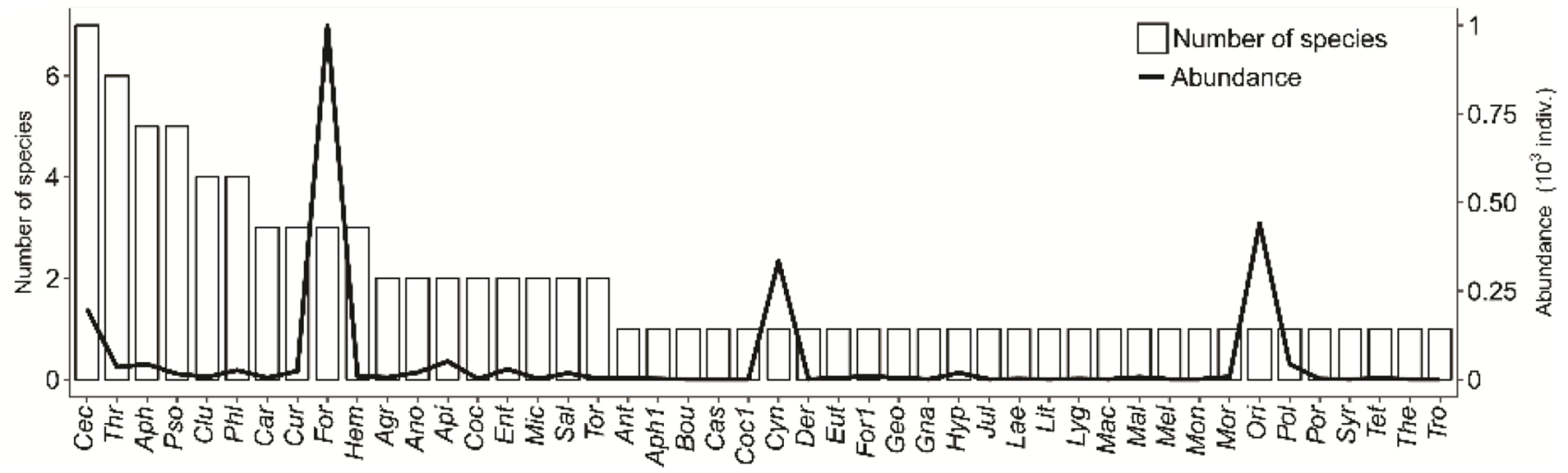

hand, in some of the richer plant families, such as Poaceae and Lamiaceae, no galls were detected, or only a small percentage of species had galls, e.g. Asteraceae (Fig. 1a).

Overall, 31,737 galls were collected, belonging to 49 species or morphospecies (hereafter referred collectively as "species") (Fig. 1b); of these only 13 gallers could not be identified to species level. The most represented and diverse families of gallers were Cynipidae and Cecidomyiidae (with 13 and 12 gall species, respectively), which were also the families with higher percentage of gall species with emergencies ( $92 \%$ and $69 \%$, respectively). When considering the abundance of gallers besides these two dominant families, a third family stands out: Eriophyidae, with only two species of very abundant gallers (Fig. 1b).

As for parasitoids, 11,435 insects from 65 species distributed by 17 families emerged from the galls, with families Torymidae, Eulophidae, Braconidae, Encyrtidae, Eurytomidae, Mymaridae and Pteromalidae being the ones with greater species richness (Fig. 1c). The families with higher abundance of individuals were Eulophidae, Pteromalidae, Torymidae and Eurytomidae. Although Torymidae almost is twofold the number of species of Pteromalidae, both families had similar abundance. Braconidae, 
4Fig. 1 Number of species and abundance of specimens per family of a plants, considering both species where galls were observed and species with no galls; $\mathbf{b}$ gallers; $\mathbf{c}$ parasitoids; and $\mathbf{d}$ inquilines. All field sites and samplings were considered for this analysis. Plant families: Fab (Fabaceae), Fag (Fagaceae), Cis (Cistaceae), Ast (Asteraceae), Eri (Ericaceae), Sal (Salicaceae), Ana (Anacardiaceae), Dip (Dipsacaceae), Lau (Lauraceae), Myr (Myricaceae), Ole (Oleaceae), Rha (Rhamnaceae), Ros (Rosaceae), Ama (Amaryllidaceae), Api (Apiaceae), Apo (Apocynaceae), Ara (Araceae), Asp (Asparagaceae), Bor (Boraginaceae), Bra (Brassicaceae), Cap (Caprifoliaceae), Car (Caryophyllaceae), Cra (Crassulaceae), Cup (Cupressaceae), Cyp (Cyperaceae), Eup (Euphorbiaceae), Ger (Geraniaceae), Lam (Lamiaceae), Pin (Pinaceae), Pla (Plantaginaceae), Poa (Poaceae), Pri (Primulaceae), Rub (Rubiaceae), Scr (Scrophulariaceae), Urt (Urticaceae), Oth (Others): including all families with only one plant species and without the presence of galls; Gall families: Cyn (Cynipidae), Cec (Cecidomyiidae), Api (Apionidae), Eri (Eriophyidae), Tri (Triozidae), Agr (Agromyzidae), Aph (Aphidiidae), Tep (Tephritidae), Tor (Tortricidae) and Und (Undetermined); Parasitoid families: Tor (Torymidae), Eul (Eulophidae), Bra (Braconidae), Enc (Encyrtidae), Eur (Eurytomidae), Mym (Mymaridae), Pte (Pteromalidae), Eup (Eupelmidae), Ich (Ichneumonidae), Pla (Platygastridae), Aph (Aphelinidae), Cra (Crabronidae), Cec (Cecidomyiidae), Cer (Ceraphronidae), Gas (Gasteruptiidae), Orm (Ormyridae), Pro (Proctotrupidae) and Inquiline families: Cec (Cecidomyiidae), Thr (Thripidae), Aph (Aphididae), Pso (Psocoptera), Clu (Clubionidae), Phl (Phlaeothripidae), Car (Carabidae), Cur (Curculionidae), For (Formicidae), Hem (Hemiptera: Heteroptera), Agr (Agromyzidae), Ano (Anobiidae), Api (Apionidae), Coc (Coccinellidae), Ent (Entomobryidae), Mic (Microcoryphia), Sal (Salticidae), Tor (Tortricidae), Ant (Anthocoridae), Aph1 (Aphrophoridae), Bou (Bourletidae), Cas (Cassidae), Coc1 (Coccidae), Cyn (Cynipidae), Der (Dermestidae), Eut (Eutichuridae), For1 (Forficulidae), Geo (Geophilomorpha), Gna (Gnaphosidae), Hyp (Hypogastruridae), Jul (Julidae), Lae (Laemophloeidae), Lit (Lithobiomorpha), Lyg (Lygaeidae), Mac (Machilidae), Mal (Malachiidae), Mel (Melyridae), Mon (Monophlebidae), Mor (Mordellidae), Ori (Oribatida), Pol (Polyxenidae), Por (Porcellionidae), Syr (Syrphidae), Tet (Tettigoniidae), The (Theridiidae), Tro (Trombidiidae)

Encyrtidae and Mymaridae were represented by several species, but with a very low abundance (Fig. 1c).

Finally, 2391 inquilines, distributed by 88 species and 46 families, emerged from the collected galls (Fig. 1d). The richest families were Cecidomyiidae and Thripidae, followed by a diverse array of poorly represented arthropod groups, namely: aphids (Aphidiidae), booklices (Psocoptera), spiders (Clubionidae) and thrips (Phlaeothripidae). Ants (Formicidae) and Cynipidae wasps and mites (Oribatida) were the most abundant inquilines (Fig. 1d).

Life-form and plant cover were identified as important variables that influenced the abundance $(F=4.309, d f=4$, $p=0.040$ and $F=4.361, d f=4, p=0.002$, respectively) of galls (Online Resource 2: Table 2). However, plant family was strong associated $(F=2.27, d f=166, p<0.001)$ with the richness of galls. More species of galls were found in shrubs $(0.052 \pm 0.303($ mean $\pm S D))$ and trees $(0.007 \pm 0.03)$ while only a few species were found in subshrubs and herbs (Fig. 2). However in average, abundance of galls was substantially higher on shrubs $\left(3.475 \pm 13.328\right.$ galls $/ \mathrm{m}^{2}$ of plant cover) than in subshrubs, tress and herbs $(1.26 \pm 5.227$; $0.007 \pm 0.03$ and $0.0004 \pm 0.005$ galls $/ \mathrm{m}^{2}$ of plant cover, respectively) (Fig. 2).

\section{Rank-abundance curves}

Rank-abundance curves revealed the dominance of only a few species per guild (Fig. 3; see Online Resource 2: Table 3 for details). The most abundant plant species with galls was Cistus salviifolius, followed by Artemisia campestris, Quercus coccifera, Pistacia lentiscus, Ulex europaeus, Halimium calycinum, Halimium halimifolium and Quercus robur (Fig. 3, grey line). In the case of gallers, the midge Aceria quercina (Eriophyidae) was by far the most abundant species, followed by the midges Rhopalomyia baccarum and $R$. santolinae (Cecidomyiidae), and by the wasp Plagiotrochus quercusilicis (Cynipidae) (Fig. 3, pink line).

Regarding the parasitoids that emerged from the collected galls (Online Resource 2: Table 1) (Fig. 3, green line), there were four most frequent wasps: Torymus flavipes (Torymidae) [attacking Plagiotrochus quercusilicis (Cynipidae) and Andricus kollari (Cynipidae)], Mesopolobus tibialis (Pteromalidae) (attacking the cynipid $P$. quercusilicis, Cynips sp., undeterminated Q. robur gall and the cecidomyiid Rhopalomyia baccarum), Pediobius rotundantus (Eulophidae) (attacking P. quercusilicis) and Sycophila variegata (Eurytomidae) (attacking $P$. quercusilicis and the cecidomyiid Contarinia sp.). Finally, concerning inquilines (Fig. 3, blue line), the ants (Temnothorax sp.), the mites (mainly Acari: Oribatidae), the cynipid Synergus sp. and the Cecidomyiidae Clinodiplosis sp. were the most abundant and dominated over all other groups.

\section{Monthly phenology and turnover}

The number of species per guild was highly variable throughout the year (Fig. 4, Online Resource 1: Figure 2), but there was a trend for a higher diversity in winter and spring (Fig. 4). Although the number of plant species per month was high (usually above 40 species, Fig. 4a), only about $20-30 \%$ of those had galls ( $\min .=10$; $\max .=14$ species, Fig. 4a). Approximately, the same numbers of galler and parasitoid species were observed per month (6-16 galler species and 6-19 parasitoid species; Fig. 4b, c), while inquiline diversity was lower (ranging from 1 to 13 , Fig. 4d).

Species turnover rates were generally above $50 \%$ and somewhat variable for all guilds (Fig. 4). Plants showed the lower turnover rates $($ mean $=31.9 \%$; $\min .=8.3 \%$; $\max .=46.7 \%)$, followed by gallers with values around $50 \%(\operatorname{mean}=49.6 \% ; \min .=27.3 \% ; \max .=71.4 \%)$, while parasitoids $(\operatorname{mean}=60.1 \% ; \min .=37.5 \% ; \max .=76.2 \%)$ and inquilines $(\operatorname{mean}=87.8 \% ; \min .=70 \% ; \max .=100 \%)$ 
Table 1 Habitat classification and conservation status of each sampling sites

\begin{tabular}{|c|c|c|c|c|}
\hline & Site (coordinates) & Dominant plant species & Habitat type & Conservation status \\
\hline \multirow[t]{5}{*}{$\begin{array}{l}\text { Sites sampled } \\
\text { every } \\
\text { month }\end{array}$} & $\begin{array}{l}\text { Quaios1 } \\
\text { (Lat: } 40.22476 \\
\text { Lon: }-8.88622)\end{array}$ & $\begin{array}{l}\text { Artemisia campestris L. } \\
\text { Carpobrotus edulis (L.) N.E.Br } \\
\text { Corema album (L.) D.Don } \\
\text { Crucianella maritima L. }\end{array}$ & Sand Dune & National Forest Natura 2000 Network \\
\hline & $\begin{array}{l}\text { Quiaios } 2 \\
\text { (Lat: } 40.251896 \\
\text { Lon: }-8.798968)\end{array}$ & $\begin{array}{l}\text { Pinus pinaster Aiton } \\
\text { Corynephorus sp. P.Beauv } \\
\text { Halimium halimifolium (L.) Willk } \\
\text { Scirpoides holoschoenus (L.) Soják }\end{array}$ & Pine forest & Natura 2000 Network \\
\hline & $\begin{array}{l}\text { Boa Viagem } \\
\text { (Lat: } 40.20037 \\
\text { Lon: }-8.88969)\end{array}$ & $\begin{array}{l}\text { Pistacia lentiscus } \mathrm{L} . \\
\text { Cistus salviifolius } \mathrm{L} . \\
\text { Smilax aspera } \mathrm{L} . \\
\text { Rosmarinus officinalis } \mathrm{L} .\end{array}$ & Oak woodland & National Forest \\
\hline & $\begin{array}{l}\text { Coimbra } \\
\text { (Lat: } 40.18588 \\
\text { Lon: }-8.41358)\end{array}$ & $\begin{array}{l}\text { Quercus robur } \mathrm{L} . \\
\text { Arbutus unedo } \mathrm{L} . \\
\text { Quercus suber } \mathrm{L} . \\
\text { Ulex minor Roth }\end{array}$ & Oak woodland & - \\
\hline & $\begin{array}{l}\text { São Pedro de Moel } \\
\text { (Lat: } 39.75711 \\
\text { Lon: }-9.02338)\end{array}$ & $\begin{array}{l}\text { Pinus pinaster Aiton } \\
\text { Cistus salviifolius } \mathrm{L} . \\
\text { Quercus coccifera } \mathrm{L} . \\
\text { Phillyrea angustifolia } \mathrm{L} .\end{array}$ & Pine Forest & National Forest \\
\hline \multirow[t]{5}{*}{$\begin{array}{l}\text { Sites sampled } \\
\text { every } \\
3 \text { months }\end{array}$} & $\begin{array}{l}\text { Santo André } \\
\text { (Lat: } 37.993975 \\
\text { Lon: }-8.850893 \text { ) }\end{array}$ & $\begin{array}{l}\text { Santolina impressa Hoffmanns. and Link } \\
\text { Stauracanthus spectabilis Webb } \\
\text { Artemisia campestris L. } \\
\text { Halimium calycinum } \text { (L.) K.Koch }\end{array}$ & Sand Dune & Natural Reserve, Natura 2000 Network \\
\hline & $\begin{array}{l}\text { Esposende } \\
\text { (Lat: } 41.508999 \\
\text { Lon: }-8.784351)\end{array}$ & $\begin{array}{l}\text { Artemisia campestris } \mathrm{L} . \\
\text { Ammophila arenaria } \text { H.Lindb } \\
\text { Cistus salviifolius } \mathrm{L} . \\
\text { Aetheorhiza bulbosa Cass }\end{array}$ & Sand Dune & Natural Park, Natura 2000 Network \\
\hline & $\begin{array}{l}\text { São Jacinto } 1 \\
\text { (Lat: } 40.698608 \\
\text { Lon: }-8.735636)\end{array}$ & $\begin{array}{l}\text { Artemisia campestris } \mathrm{L} . \\
\text { Carpobrotus edulis } \text { (L.) N.E.Br } \\
\text { Corema album (L.) D.Don } \\
\text { Helichrysum italicum subsp. picardii (Boiss. } \\
\text { and Reut.) Franco }\end{array}$ & Sand Dune & Natural Reserve, Natura 2000 Network \\
\hline & $\begin{array}{l}\text { São Jacinto2 } \\
\text { (Lat: } 40.697669 \\
\text { Lon: }-8.729265 \text { ) }\end{array}$ & $\begin{array}{l}\text { Cistus salviifolius } \mathrm{L} . \\
\text { Pinus pinaster Aiton } \\
\text { Avena sterilis } \mathrm{L} . \\
\text { Ulex europaeus } \mathrm{L} .\end{array}$ & Pine Forest & Natural Reserve, Natura 2000 Network \\
\hline & $\begin{array}{l}\text { Tocha } \\
\text { (Lat: } 40.34837 \\
\text { Lon: }-8.81704)\end{array}$ & $\begin{array}{l}\text { Stauracanthus genistoides (Brot.) Samp } \\
\text { Pinus pinaster Aiton } \\
\text { Halimium halimifolium }(\mathrm{L} .) \text { Willk } \\
\text { Cistus salviifolius L. }\end{array}$ & Pine Forest & National Forest Natura 2000 Network \\
\hline
\end{tabular}

showed high turnover rates changing almost all species in some consecutive months (Fig. 4).

As for general specimens' abundance, more galls were collected and more insects emerged from these galls during late spring, mostly in April to June (Online Resource 2: Table 5).

\section{Insect emergence}

At least some individuals of all insect guilds emerged throughout the year, however, each guild showed a characteristic phenology (Fig. 5). Gallers emerged mainly from late April to late June, with only smaller peaks outside this period. For parasitoids, there were two nearly overlapping peaks in mid-May and mid-June. Finally, the emergence of inquilines (Fig. 5a) was more evenly distributed throughout the year, with only two broad peaks in early-April and June. Differences in the mean emergence date of the different guilds were statistically significant $\left(H^{2}=1776.8, p<0.05\right)$, with inquilines "emerging" earlier than gallers and parasitoids (Fig. 5b).

When considering the number of days that insects took to emerge after collection of the galls in the field, most insects emerged within a month, but there was a large variation and some insects emerged only after ca. 6 months (Fig. 6a). When median values were analysed, gallers emerged in 


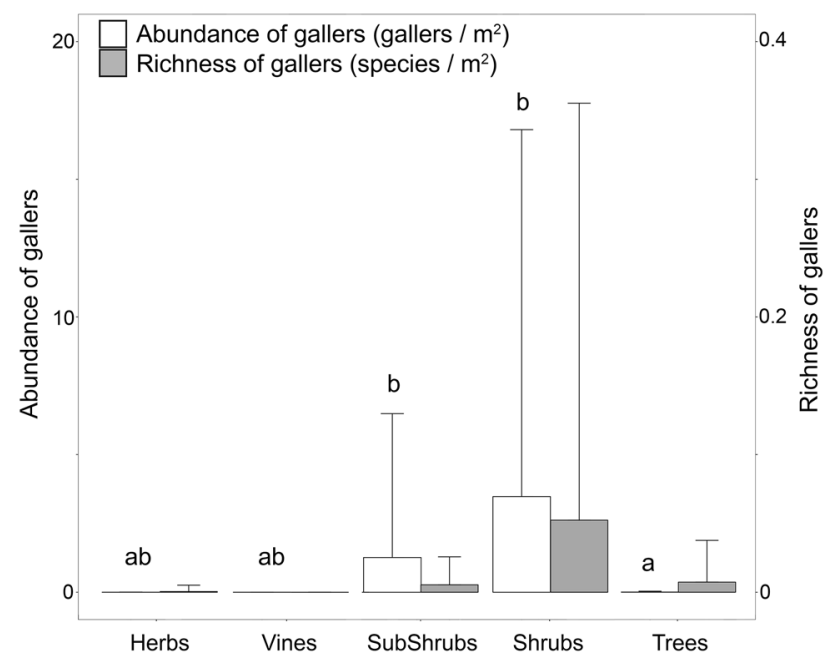

Fig. 2 Average richness and abundance of galler species according to the life-form of the host plants. Error bars show the standard deviation. Letters above bars show the results of the multiple comparison of means by Tukey test

14 days $(\min .=0 ; \max .=284)$, followed by parasitoids that emerged in 17 days $(\min .=0$; $\max .=389)$, and inquilines in 49 days ( $\min .=0$; max. $=335$, Fig. 6b); differences on the time until emergence were statistically significant $\left(H^{2}=5236, p<0.05\right)$ for all guilds (Fig. $6 \mathrm{~b}$ ).

\section{Discussion}

Our results show a remarkable diversity associated with gall communities in Portuguese coastal habitats, as well as a strong temporal structure of such communities. In comparison with previous taxonomic studies of Iberia, our study revealed a relatively richer community of galls, parasitoids and inquilines (Nieves-Aldrey 2001a; Skuhravá et al. 1996,
2006). As could be anticipated, more gall species were observed in large plant families, particularly in Fabaceae and in families frequently associated with galls in the northern hemisphere such as Fagaceae and Cistaceae (NievesAldrey 2001a; Ronquist et al. 2015). Considering the 140 species of Cynipidae described for the Iberian Peninsula and Balearic Islands (Nieves-Aldrey 2001a) and the 122 species of Cecidomyiidae given for Portugal (Skuhravá and Skuhravý 2009), it was found a considerable percentage of such species $(9.3 \%$ and $10.3 \%$ of Cynipidae and Cecidomyiidae, respectively) only in coastal habitats. This is even more surprising considering the range of plant species observed in such habitats, many of which were not associated with galls (Fig. 1a). Moreover, plants species that are typically known to harbour many gall species, particularly Quercus spp. (Skuhravý et al. 1998; Stone and Cook 1998), were absent from most study sites, although they had galls whenever present. Eriophyidae, which is also an important gallinducing family (Amrine and Stasny 1994), was represented only by two species, although very abundant due to Aceria quercina, the most frequent gall species in our study, forming small copious galls in the leaves of Quercus coccifera .

As for parasitoids and inquilines, several families cooccurred in the same gall species some of which co-occured simultaneously. But while parasitoids belonged to a few families with several representatives, inquilines were generally scattered among many families, within different orders, each of them represented by only a few species. This reflects, on one hand the complex morphologies of some galls (e.g. Plagiotrochus quercusilicis with different morphotypes) that provided more niches for several inquilines, and on the other hand the lower physiological constraints for inquilines as many of them only use the gall as a protective structure. In fact, although all inquilines were included in the same category, it must be acknowledged that their ecology and life-history traits may be quite diverse (Sanver and Hawkins
Fig. 3 Rank-abundance curves of plants with galls, gallers, parasitoids and inquilines in Portuguese coastal habitats. Species abundance ranks were based on plant cover $\left(\mathrm{m}^{2}\right)$ and abundance of individuals of each animal guild (gallers, parasitoids and inquilines), see Online Resource 2 and Table 3 for details

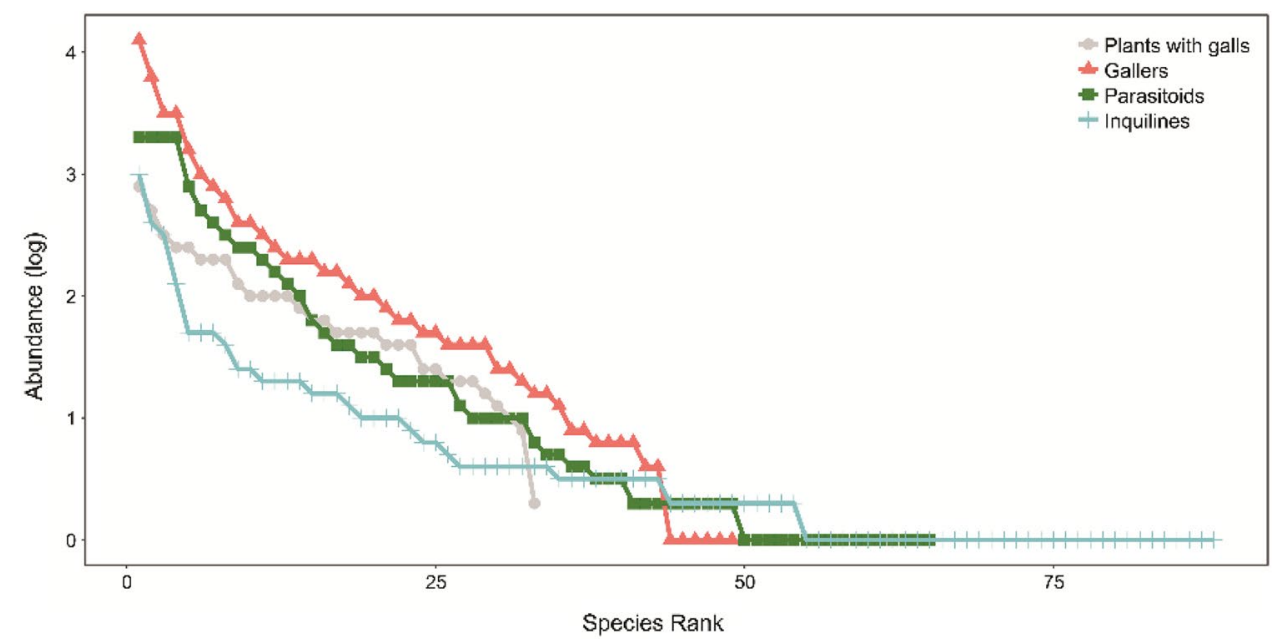


(a)

(b)

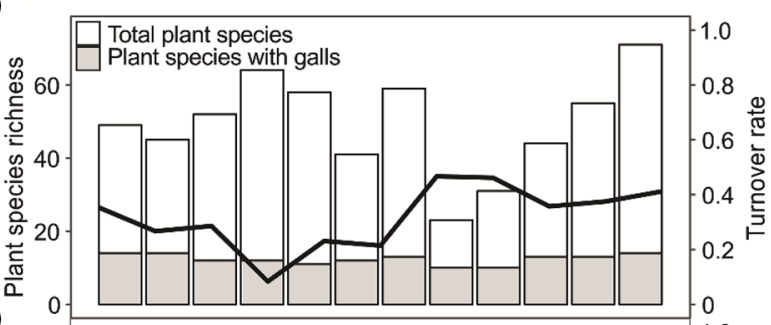

(c)

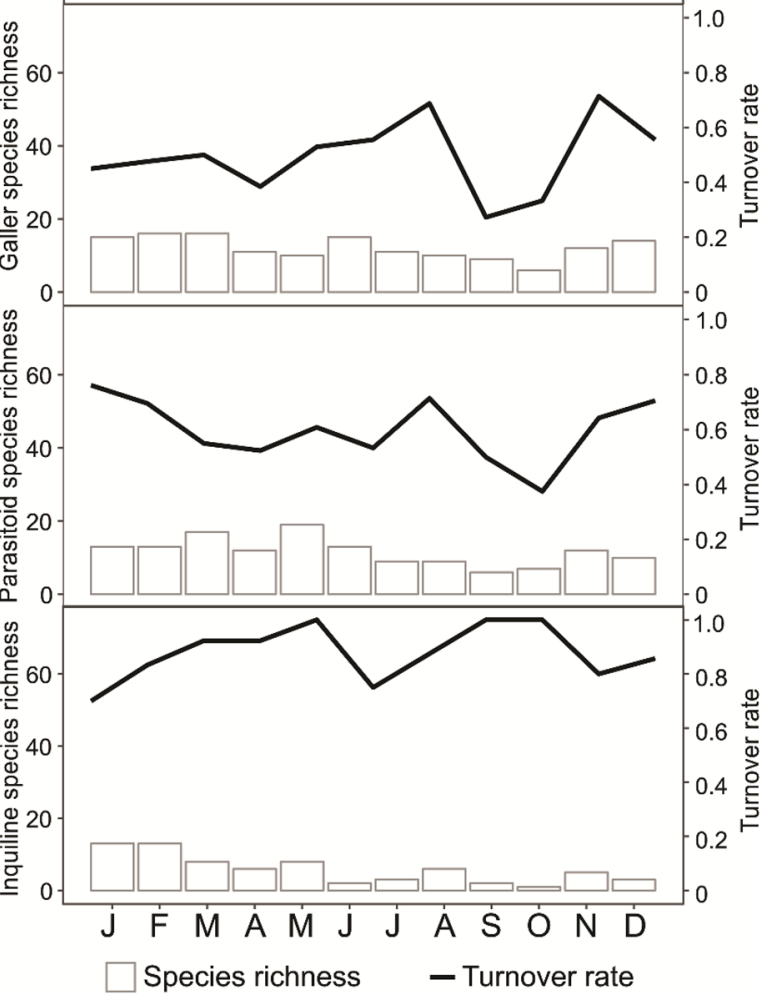

Fig. 4 Number of species (bars) and monthly turnover rate (lines) for a plants, $\mathbf{b}$ gallers, $\mathbf{c}$ parasitoids and $\mathbf{d}$ inquilines. Only data from the sites sampled every month were considered for these analyses

2000). For example, the cynipoid inquiline Synergus feeds within the gall tissues (Nieves-Aldrey 2001a), while many spiders, ants and beetles only use the gall as shelter or nest site (Blanche 2012). Additionally, parasitoids are likely more specialized, due to the physiological requirements of this intimate interaction, while the relationship between galls and inquilines is less constrained and therefore more generalized (Paniagua et al. 2009). The diverse gall morphology observed may have also contributed for the diversity of species parasitizing them, e.g. parasitoids with long ovipositors can easily reach the galler chamber in large galls, while species with short ovipositors prefer smaller galls or galls with peripheric chambers (Joseph et al. 2011).

Accordingly, we found that parasitoids of Plagiotrochus quercusilicis (Cynipidae; $<1 \mathrm{~cm}$ plurilocular gall formed on Quercus coccifera) were mainly Torymids (Torymus spp.) with long ovipositors, while parasitoids of

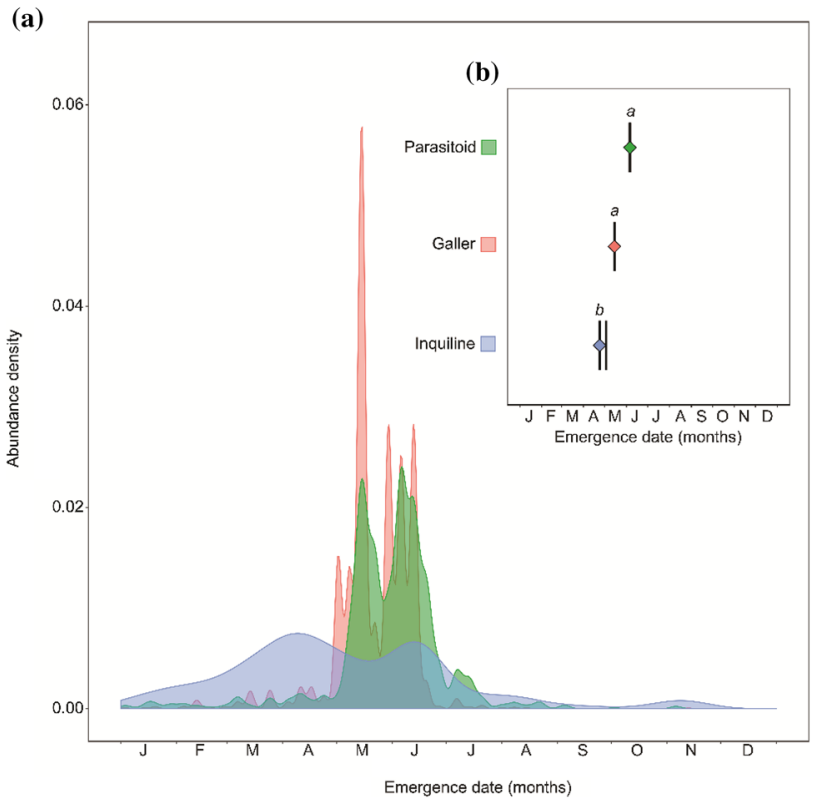

Fig. 5 Annual phenology of insect guilds emerging from collected galls. a Emergence phenology, b median emergence time and 95\% confidence intervals of the bootstrapped median. Only the data from the four sites sampled in each month were included in this analysis

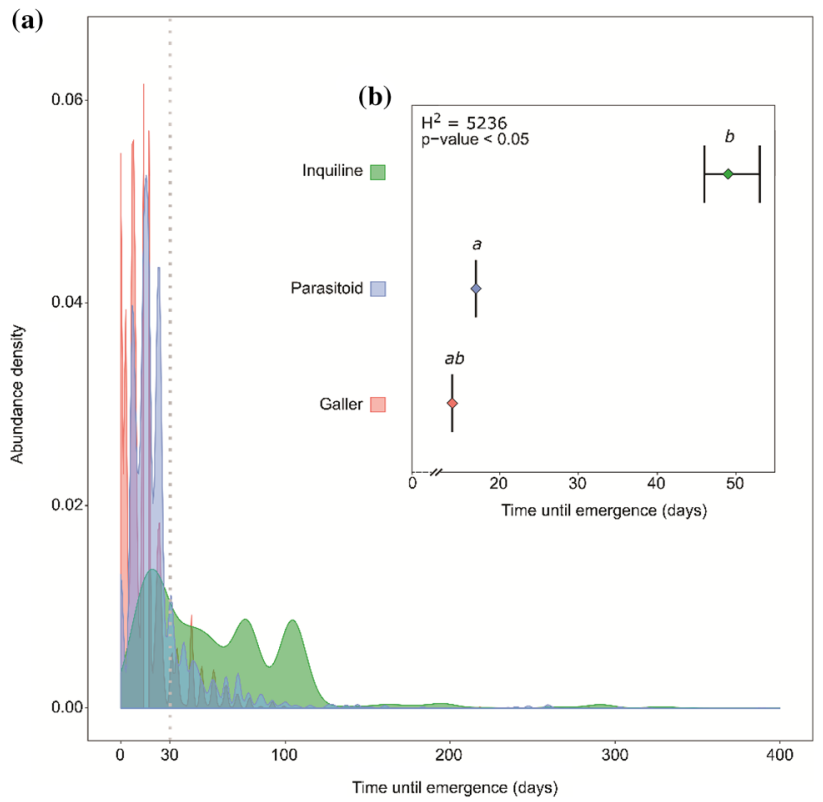

Fig. 6 Time until insect emergence per guild. a Distribution of emergence frequency, b median time until emergence per guild and $95 \%$ confidence intervals of the bootstrapped median. All field sites and samplings were considered for this analysis

Rhopalomyia baccarum (Cecidomyiidae; $<0.5 \mathrm{~cm}$ unilocular gall from Artemisia campestris) were mostly Pteromalids (Mesopolobus spp.) and Eulophids (Aprostocetus spp.) 
with short ovipositors. Species of Torymidae, Eulophidae and Pteromalidae known to parasitize Cynipidae and Cecidomyiidae (Goulet and Huber 1993; Grissell 1995) were very common in our sites, suggesting that these two gall families represent important trophic resources for parasitoids.

As often documented for biological communities, insect guilds, particularly parasitoids and inquilines, were dominated by a few very abundant species and by a long tail of rare species (Fisher et al. 1943; Preston 1948). Most study sites were spatially heterogeneous with high plant diversity, including a mixture of plant species and life-forms that frequently promote gall formation, e.g. oak woodlands included Quercus coccifera, $Q$. robur and Ulex spp., sand dunes had Artemisia campestris and Cistus salviifolius, pine forests included several species of Halimium and there were several schlerophiyllous plant species (such as Stauracanthus spp. and Ulex spp.) which are reported to frequently form galls (Fernandes and Price 1992). This means that the high spatial heterogeneity in environmental conditions associated with the distribution of host plants, and possibly asynchronous plant phenology may have conferred high diversity of niches all year long for different gallers and consequently parasitoids and inquilines. As expectable, galls predominate on shrubs and trees (Cuevas-Reyes et al. 2004; Lawton 1983), a vast majority of galls species on littoral habitats of Portugal were observed in shrubs and trees, while the abundance was higher in shrubs and subshrubs, suggesting that such plant life-forms are important for maintaining diverse gall communities in these habitats. Consequently, disturbances that keep habitats into early successional stages or prevent diversity and abundance of shrubs and trees, such as frequent fires, overgrazing or invasive plants, can negatively affect gall communities (see López-Núñez et al. 2017).

Even though turnover rates revealed a high variation in gall communities along the whole year, richness and abundance of galls and insects tended to be higher during winter and spring. This may be partially explained because gall communities are coupled with the life cycles of the host plants, since the development of meristematic tissues and the growth of young buds are essential for gall development (Redfern and Shirley 2011), which occurs in spring in Mediterranean ecosystems. It must be noticed that because our sampling was destructive, we had to sample different transects each month and as such the plant species were not always exactly the same, although transects were in the same habitat type; since gallers are highly specific, this type of sampling necessarily influenced the turnover rate beyond the normal seasonal variation. Nevertheless, the turnover of gallers, parasitoids and inquilines was greater than that of plants, suggesting that high turnover rates are mostly a consequence of intrinsic insect phenology and not a simple consequence of different plant communities.
Regarding insect phenology, parasitoids and inquilines can only enter the galls after the gallers and consequently they usually emerge later. In general, gallers were the first to emerge followed by parasitoids and later by inquilines, suggesting an inter-guild regulation with a lag-time, which, together with variable environmental conditions, is likely to cause fluctuations in the seasonal dominance of the different guilds (Ananthakrishnan 1998). The presence of several peaks of galler emergence could be explained either by the presence of galler species with multiple generations through the year, as is the case of Plagiotrochus quercusilicis, by the emergence of multiple generations from the same gall, or can be an artefact related to the context-specific sampling of each month (i.e. different transects and different environmental conditions in each visit). As for parasitoids, the infection of the galler larvae is generally performed during the first stages of gall development (Askew 1961), and parasitoids usually take longer until they are ready to emerge and complete their life cycle, explaining why they emerge slightly after the gallers. Inquilines have a broad ecological amplitude in terms of the galls used as many of them are only looking for shelter and tend to use the galls only after the gallers or parasitoids have already emerged (Sanver and Hawkins 2000). In this context, although galls are frequently ignored as an important biological resource, gall communities can provide resources across the whole year, which might be important for many insectivorous species. Additionally, the galls themselves may be a precious resource through the year, making them an interesting niche exploited by several groups of terrestrial mesofauna. For example, several large herbivores, such as goats, are known to specifically search for galls while foraging (Otília, pers. commun).

As in any ecological study, the observed species richness and abundances should be interpreted as minimum reference values. First, because despite the high investment in fieldwork, considering different sites and habitats and the yearlong sampling, we might still have missed some of the species present. Secondly, because we have only detected insect emergencies in $21 \%$ of all collected galls. This low emergence rate may be explained by several reasons, namely (1) some gallers or parasitoids may have emerged in the field before the galls were collected, (2) some gallers may have been killed by parasitoids failing to complete their cycle, and (3) the optimal conditions for the development of insects may have not been reached for all species in the lab. These limitations are common to all studies involving insect rearing in laboratorial conditions (Fisher et al. 1999).

In conclusion, and despite a relatively low emergence rate, our results revealed highly diverse gall communities in coastal habitats, both in terms of richness and abundance of these underexplored guilds. Turnover rates and phenology of the different guilds provide a much deeper 
understanding of the dynamics of gall communities and revealed how different guilds dominate these poorly known communities along the year, potentially affecting other species that depend on these resources. Naturally, the composition, structure and resilience of these communities are contingent upon several biotic and environmental factors. Therefore, the baseline information reported here is likely to prove highly valuable in the future to monitor community changes as a response of the many external threats such as biological invasions and climate change.

Acknowledgements We are grateful for the commitment of many dedicated field personnel: P. Castro, S. Carvalho, L. Barrico, N. César de Sá, J. Cerca, J. Costa, A. Martins, D. Alves, E. Almeida and D. Barros-García; and the professional taxonomist consulted for arthropods identification, including N. Dorchin, L. Friedman, L. Crespo, J.L. Grosso-Silva, M. Alonso-Zarazaga, F. Di Giovanni, G. Broad, A. Polaszek, H. Vardal, A. Franquinho Aguiar, F. Chichorro, C. Prado e Castro, A. M. Ortega, A. R. Gonçalves, and the involved institutions such as Natural History Museum of London and National Research College of Veterinary and Agronomy of Portugal. RHH was funded by grant IF/00441/2013 of the Portuguese Foundation for Science and Technology (FCT). This research and FLN were supported by FCT and COMPETE/FEDER, through project "INVADER-B-INVAsive plant species management in Portugal: from early Detection to Remote sensing and Biocontrol of Acacia longifolia" (PTDC/AAGREC/4896/2014).

\section{Compliance with Ethical Standards}

Conflict of interest The authors declare that they have no conflict of interest.

\section{References}

Aebi A, Schönrogge K, Melika G, Quacchia A, Alma A, Stone GN (2007) Native and introduced parasitoids attacking the invasive chestnut gall wasp Dryocosmus kuriphilus. EPPO Bull 37:166-171

Amrine JW, Stasny TA (1994) Catalog of the Eriophyoidea (Acarina: Prostigmata) of the World. Indira Publishing House, West Bloomfield

Ananthakrishnan TN (1998) Insect gall systems: patterns, processes and adaptive diversity. Curr Sci 75:672-676

Askew RR (1961) A study of the biology of species of the genus Mesopolobus (Hymenoptera: Pteromalidae) associated with cynipid galls on oaks. Trans R Entomol Soc Lond 113:155-173

Askew RR, Plantard O, Gómez JF, Nieves MH, Nieves-Aldrey JL (2006) Catalogue of parasitoids and inquilines in galls of aylacini, diplolepidini and pediaspidini (Hym., Cynipidae) in West Palearctic. Zootaxa 1301:1-60

Askew RR, Melika G, Pujade-Villar J, Schönrogge K, Stone GN, Nieves-Aldrey JL (2013) Catalogue of parasitoids and inquilines in cynipid oak galls in the Western Palaearctic. Zootaxa 3643(1):1-133

Bates D, Mächler M, Bolker B, Walker S (2015) Fitting linear mixedeffects models using \{lme4\}. J Stat Softw 67:1-48

Begon M, Harper JL, Townsend CR (1999) Ecología: individuos, poblaciones y comunidades. Omega, Barcelona
Bellido D, Pujade-Villar J (1999) Aproximació al coneixement de la biogeografia de la tribu Cynipini (Hymenoptera: Cynipoidea: Cynipidae) a la Regió Paleàrtica. Ses entom ICHN-SCL 11:67-79

Bingre P, Aguiar C, Espírito-Santo D, Arsénio P, Monteiro-Henriques T (2007) Guia de campo: árvores e arbustos de Portugal Continental. Fundação Luso-Americana para o Desenvolvimento/ Liga para a Protecção da Natureza, Jornal Público, Lisboa

Blanche R (2012) Life in a gall: the biology and ecology of insects that live in plant galls. CSIRO Publishing, Collingwood

Branco M, Franco JC, Valente C, Mendel Z (2006) Survey of Eucalyptus gall wasps (Hymenoptera: Eulophidae) in Portugal. Boletin Sanidad Plagas Vegetales 32:199-202

Branco M, Boavida C, Durand N, Franco JC, Mendel Z (2009) Presence of the Eucalyptus gall wasp Ophelimus maskelli and its parasitoid Closterocerus chamaeleon in Portugal: first record, geographic distribution and host preference. Phytoparasitica 37:51-54

Brian MV (2012) Social insects: ecology and behavioural biology Springer, Berlin

Brooks SE, Shorthouse JD (1998) Developmental morphology of stem galls of Diplolepis nodulosa (Hymenoptera:Cynipidae) and those modified by the inquiline Periclistus pirata (Hymenoptera:Cynipidae) on Rosa blanda (Rosaceae). Can J Bot 76(3):365-381

Brussino G, Bosio G, Baudino M, Giordano R, Ramello F, Melika G (2002) Pericoloso insetto esotico per il castagno europeo. L'Informatore Agrario 37:59-62

Bunnefeld L, Hearn J, Stone GN, Lohse K (2018) Whole-genome data reveal the complex history of a diverse ecological community. PNAS 115:E6507-E6515

Chinery M (2013) Britain's plant galls: a photographic guide. Princeton University Press, Hampshire

Collins S, Suding KN, Cleland EE, Batty M, Pennings SC, Gross KL, Grace JB, Gough L, Fargione JE, Clark CM (2008) Rank clocks and plant community dynamics. Ecology 89:3534-3541

Copping LG (2009) The manual of biocontrol agents: a World compendium. Ed. 4. British Crop Production Council, London

Csóka G, Stone GN, Melika G (2005) The biology, ecology and evolution of gall wasps. In: Raman A, Schaeffer CW, Withers TM. Biology, ecology and evolution of gall-inducing arthropods. Science Publishers Inc., Enfield. pp 573-642

Csóka G, Stone N, Melika GG (2017) Non-native gall-inducing insects on forest trees: a global review. Biol Invasions 19:3161-3181

Cuevas-Reyes P, Quesada M, Hanson P, Dirzo R, Oyama K (2004) Diversity of gall-inducing insects in a Mexican tropical dry forest: the importance of plant species richness, life-forms, host plant age and plant density. J Ecol 92:707-716

Dorchin N, Hoffmann JH, Stirk WA, Novák O, Strnad M, Van Staden J (2009) Sexually dimorphic gall structures correspond to differential phytohormone contents in male and female wasp larvae. Physiol Entomol 34:359-369

EPPO Reporting Service no. 06-2014; Num. article: 2014/103, First report of Dryocosmus kuriphilus in Portugal

Fernandes GW, Price PW (1992) The adaptive significance of insect gall distribution: survivorship of species in xeric and mesic habitats. Oecologia 90:14-20

Fisher RA, Corbet AS, Williams CB (1943) The relation between the number of species and the number of individuals in a random sample of an animal population. J Anim Ecol 12:42-58

Fisher TW, Bellows TS, Caltagirone LE, Dahlsten DL, Huffaker CB, Gordh G (1999) Handbook of biological control: principles and applications of biological control. Elsevier, New York

Franco JA (1971) Nova Flora de Portugal Continental (Continente e Açores), (Licopodiaceae-Umbelliferae). Vol. I Lisboa

Franco JA (1984) Nova Flora de Portugal Continental (Continente e Açores), (Clethraceae-Compositae). Vol. II, Lisboa 
Franco JA, Rocha Afonso M (1994) Nova Flora de Portugal (Continente e Açores), vol.III (fascículo I), Alismataceae-Iridaceae. Escolar Editora, Lisboa

Franco JA, Rocha Afonso M (1998) Nova Flora de Portugal (Continente e Açores), vol.III (fascículo II), GRAMINEAE. Escolar Editora, Lisboa

Franco JA, Rocha Afonso M (2003) Nova Flora de Portugal (Continente e Açores), vol.III (fascículo III), JUNCACEAE-ORCHIDACEAE. Escolar Editora, Lisboa

Garbin L, Díaz N, Pujade-Villar J (2008) Experimental study of the reproductive cycle of Plagiotrochus amenti Kieffer, 1901 (Hymenoptera, Cynipoidea, Cynipidae), with comments on tis taxonomy. Boletin Asociación Española de Entomología 32:341-349

Giron D, Huguet E, Stone GN, Body M (2016) Insect-induced effects on plants and possible effectors used by galling and leaf-mining insects to manipulate their host-plant. J Insect Physiol 84:70-89

Goulet H, Huber J (1993) Hymenoptera of the World: an Identification guide to families 1. In: Goulet H, Huber J (eds), Ottawa: Agriculture Canada. Research Branch

Grissell EE (1995) Toryminae (Hymenoptera: Chalcidoidea: Torymidae): a redefinition, generic classification, and annotated world catalog of species. vol 2. Associated Publishers, Washington, DC

Hallett L, Jones SK, MacDonald AA, Flynn DFB, Slaughter P, Ripplinger J, Collins SL, Gries CJ, Matthew B (2016) \{codyn\}: Community Dynamics Metrics. https://github.com/laurenmh/codyn. Accessed 23 July 2016

Hawkins BA, Goeden RD (1984) Organization of a parasitoid community associated with a complex of galls on Atriplex spp. in southern California. Ecol Entomol 9:271-292

Hayward A, Stone GN (2005) Oak gall wasp communities: evolution and ecology. Basic Appl Ecol 6:435-443

Heslenfeld P, Jungerius PD, Klijn JA (2004) European coastal dunes: Ecological values, threats, opportunities and policy development. In: Martínez ML, Psuty NP (eds) Coastal dunes: ecology and conservation. Springer, Berlin, pp 335-351

Hewitt GM (2011) Mediterranean peninsulas: the evolution of hotspots. In: Zachos FE, Habel JC (eds) Biodiversity hotspots: distribution and protection of conservation priority areas. Springer, Berlin, pp 123-147

Hoffmann JH, Impson FAC, Moran VC, Donnelly D (2002) Biological control of invasive golden wattle trees (Acacia pycnantha) by a gall wasp, Trichilogaster sp. (Hymenoptera:Pteromalidae), in South Africa. Biolog Control 25:64-73

Holt RD, Lawton JH (1993) Apparent competition and enemy-free space in insect host-parasitoid communities. Am Nat 142:623-645

Hothorn T, Bretz F, Westfall P (2008) Simultaneous inference in general parametric models. Biometrical J 50:346-363

Impson FAC, Kleinjan CA, Hoffmann JH, Post JA (2008) Dasineura rubiformis (Diptera:Cecidomyiidae), a new biological control agent for Acacia mearnsii in South Africa. S Afr J Sci 104:247-250

Inácio ML, Naves P, Moreira M, Sousa EM (2002) Gall inducing insects associated with oak trees (Quercus spp.) in Portugal. Integrated Protect Oak Forests IOBC/wprs Bull 25:159-162

Joseph MB, Gentles M, Pearse IS (2011) The parasitoid community of Andricus quercuscalifornicus and its association with gall size, phenology, and location. Biodivers Conserv 20:203-216

Jürgen Buhr H (2012) Webseite der Fotogalerie Pflanzengallen. http:// www.pflanzengallen.de/. Accessed 1 Jan 2014

Kaartinen R, Stone GN, Hearn J et al (2010) Revealing secret liaisons: DNA barcoding changes our understanding of food webs. Ecol Entomol 35:623-638

László Z, Tóthmérész B (2006) Inquiline effects on a multilocular gall community. Acta Zool Academiae Sci Hungaricae 52:373-383

Lawton JH (1983) Plant architecture and the diversity of phytophagous insects. Annu Rev Entomol 28:23-39
López-Núñez FA, Heleno RH, Ribeiro S, Marchante H, Marchante E (2017) Four-trophic level food webs reveal the cascading impacts of an invasive plant targeted for biocontrol. Ecology 98:782-793

Losey JE, Vaughan M (2006) The economic value of ecological services provided by insects. Bioscience $56: 311$

Marchante H, López-Núñez FA, Freitas H, Hoffmann JH, Impson FAC, Marchante E (2017) First report of the establishment of the biocontrol agent Trichilogaster acaciaelongifoliae for control of invasive Acacia longifolia in Portugal. EPPO Bull https ://doi.org/10.1111/epp.12373.

Moran PJ, Goolsby JA (2009) Biology of the galling wasp Tetramesa romana, a biological control agent of giant reed. Biol Control 49:169-179

Nafría JMN, Durante MPM (2002) Hemiptera: aphididae II. Museo Nacional de Ciencias Naturales, Consejo Superior de Investigaciones Científicas, Madrid

Nieves-Aldrey JL (2001a) Fauna Iberica: 16: Hymenoptera:Cynipidae. Consejo Superior de Investigaciones Científicas, Madrid

Nieves-Aldrey JL (2001b) Nuevos datos faunísticos, corológicos y biológicos sobre los cinípidos del ámbito Íbero-Balear. Graellsia 57:39-72

Nieves-Aldrey JL, Askew RR (2002) Calcidoideos (Hym., Chalcidoidea) asociados a agallas de Aylacini y Diplolepidini (Hym., Cynipidae) en España. Boletin Asociación Española de Entomología 26:11-37

Noyes JS (2016) Universal Chalcidoidea Database. World Wide Web electronic publication. http://www.nhm.ac.uk/chalcidoids Accessed 1 Jan 2016

Ogle DH (2016) FSA: Fisheries Stock Analysis. R package version 0.8.11. https://cran.r-project.org/web/packages/FSA/index.html. Accessed 23 July 2016

Oksanen J, Blanchet FG, Kindt R, Legendre P, Minchin PR, O'Hara RB, Simpson GL, Solymos P, Henry M, Stevens H, Wagner H (2013) vegan: Community ecology package.https://cran.r-proje ct.org/web/packages/vegan/index.html. Accessed 23 July 2016

Paniagua MR, Medianero E, Lewis OT (2009) Structure and vertical stratification of plant galler-parasitoid food webs in two tropical forests. Ecol Entomol 34:310-320

Preston FW (1948) The commonness, and rarity, of species. Ecology 29:254-283

Price PW, Fernandes GW, Lara ACF, Brawn J, Barrios H, Wright MG, Ribeiro SP, Rothcliff N (1998) Global patterns in local number of insect galling species. J Biogeogr 25:581-591

Pujade-Villar J, Ros-Farré P (1998) Inquilinos y parasitoides de las agallas del género Plagiotrochus Mayr colectadas en el Nordeste de la Península Ibérica. Boletin Asociación Española de Entomología 22:115-143

Quacchia A, Ferracini C, Nicholls JA, Piazza E, Saladini MA, Tota F, Melika G, Alma A (2013) Chalcid parasitoid community associated with the invading pest Dryocosmus kuriphilus in northwestern Italy. Insect Conserv Diver 6:114-123

R Development Core Team (2011) R: A Language and environment for statistical computing, Vienna, Austria: the R Foundation for Statistical Computing. http://www.r-project.org/. Accessed 24 July 2011

Redfern M (2011) Plant galls, 1st edn. Harper Collins Publishers, London

Redfern M, Shirley P (2002) British plant galls. Identification of galls on plants and fungi, 2nd edn. Field Studies Council Publication, London

Redfern M, Shirley P (2011) British plant galls 2nd ed., Field Studies Council Publication, London

Ronquist F, Liljeblad J (2001) Evolution of the gall wasp-host plant association. Evolution 55:2503-2522 
Ronquist F, Nieves-Aldrey JL, Buffington ML, Liu Z, Liljeblad J, Nylander JAA (2015) Phylogeny, evolution and classification of gall wasps: the plot thickens. PLOS ONE 10:1-40

Ros-Farré P, Pujade-Villar J (1998) Estudio mediante una trampa Malaise de la comunidad de cinipidos cecidógenos e inquilinos de Santa Coloma, Andorra (Hymenoptera, Cynipidae). Ecologia $12: 441-454$

Russo R (2006) Field guide to plant galls of California and other Western states. University of California Press, Oakland

Sanver D, Hawkins BA (2000) Galls as habitats: the inquiline communities of insect galls. Basic Appl Ecol 1:3-11

Shorthouse JD (1998) Role of Periclistus (Hymenoptera:Cynipidae) inquilines in leaf galls of Diplolepis (Hymenoptera:Cynipidae) on wild roses in Canada. In G. Csóka, W. J. Mattson, G. N. Stone, \& P. W. Price (Eds.). The biology of gall-inducing arthropods. US Department of Agriculture Forest Service. Technical Report NC-199, St.Paul, pp. 61-81

Skuhravá M, Skuhravý V (2009) Species richness of gall midges (Diptera:Cecidomyiidae) in Europe (West Palaearctic): biogeography and coevolution with host plants. Acta Soc Zool Bohem 73:87-156

Skuhravá M, Skuhravy V, Pujade-Villar J (1996) Gall midges (Díptera:Cecidomyiidae) of the Iberian Península. Boletin Asociación Española de Entomología 20:41-61

Skuhravá M, Skuhravý V, Blasco-Zumeta J, Pujade-Villar J (2006) Gall midges (Diptera:Cecidomyiidae) of the Iberian Peninsula 2. Zoogeographical analysis of the gall midge fauna. Boletín Asociacion Española de Entomologia 30:93-159

Skuhravý V, Hrubík P, Skuhravá M, Pozgaj J (1998) Occurrence of insects associated with nine Quercus species (Fagaceae) in cultured plantations in southern Slovakia during 1987-1992. J Appl Entomol 122:149-155

Stone GN, Cook JM (1998) The structure of cynipid oak galls: patterns in the evolution of an extended phenotype. Proc R Soc B 265: 979-988

Stone GN, Schönrogge K, Rachel J et al (2002) The population biology of oak gall wasps (Hymenoptera:Cynipidae). Annu Rev Entomol 47:633-668

Tavares JS (1900) As zoocecidias portuguezas. Ann Sci Nat 8:15-108

Tavares JS (1902) As zoocecidias portuguezas. Addenda. Com a descripção de quinze especies cecidogenicas novas. Broteria $1: 3-49$

Tavares JS (1905) Synopse das zoocecidias portuguezas. Broteria $4: 4-122$

Tavares JS (1907) Primeiro appendice á Synopse das zoocecidias portuguezas. Broteria 6:109-134

Veldtman R, McGeoch MA (2003) Gall-forming insect species richness along a non-scleromorphic vegetation rainfall gradient in South Africa: the importance of plant community composition. Austral Ecol 28:1-13

Veldtman R, Lado TF, Botes A, Procheş Ş, Timm AE, Geertsema H, Chown SL (2011) Creating novel food webs on introduced Australian acacias: indirect effects of galling biological control agents. Divers Distrib 17:958-967

Whittaker RH (1965) Dominance and diversity in land plant communities. Science 147:250-260

Wilson EO (1987) The little things that run the World (the importance and conservation of invertebrates). Conserv Biol 1:344-346 